\title{
Update of the Brazilian floristic list of Algae and Cyanobacteria
}

\author{
This paper was compiled by Mariângela Menezes ${ }^{1}$, Carlos E. M. Bicudo and Carlos W. N. Moura
}

With contributions by: Aigara M. Alves; Alana A. Santos; Alexandre de G. Pedrini; Andréa Araújo; Andrea Tucci; Aurelio Fajar; Camila Malone; Cecilia H. Kano; Célia L Sant'Anna; Ciro Z. Branco; Clarisse Odebrecht; Cleto K. Peres; Emanuel B. Neuhaus; Enide Eskinazi-Leça; Eveline Aquino; Fabio Nauer; Gabriel N. Santos; Gilberto M. Amado Filho; Goia M. Lyra; Gyslaine C.P. Borges; Iara O. Costa; Ina de S. Nogueira; Ivania B. Oliveira; Joel. C.de Paula; José M. de C. Nunes; Jucicleide C. Lima; Kleber R.S. Santos; Leandro C. Ferreira;Lísia M.S. Gestinari; Luciana S. Cardoso; Marcia A.O. Figueiredo; Marcos H. Silva; Maria B.B.B. Barreto; Maria C.O. Henriques; Maria da G.G.S.Cunha; Maria E. Bandeira-Pedrosa; Maria F. Oliveira-Carvalho; Maria T.M. Széchy; Maria T.P. Azevedo; Mariana C. de Oliveira; Mariê M. Cabezudo; Marilene F. Santiago; Marli Bergesh; Mutuê T. Fujii; Norma C. Bueno; Orlando Necchi Jr.; Priscila B. Jesus; Ricardo G. Bahia; Samir Khader; Sandra M. Alves-da-Silva; Silvia M.P.B. Guimarães; Sonia M.B. Pereira; Taiara A. Caires; Thamis Meurer; Valéria Cassano; Vera R. Werner; Watson A. da Gama Jr. \& Weliton J. da Silva.

\begin{abstract}
An updated synthesis of cyanobacteria and algae information is presented for Brazil aiming to refine the data gathered to date and evaluate the progress of the biodiversity knowledge about these organisms in the country since the publication of the Catálogo de Plantas e Fungos do Brasil. The results of 2015 showed an increase of 1,250 species (35.7\%) when compared to 2010 , reaching a total of 4,747 species. The most diverse classes in species number were the Bacillariophyceae, Conjugatophyceae, Florideophyceae, Cyanophyceae, Dinophyceae and Euglenophyceae. Bacillariophyceae and Cyanophyceae had the highest increase in species number in the five-year interval. The Southeast and South regions were the most diverse, however, the Northeast, with the states of Piauí and Sergipe, and the Central-west region, with Mato Grosso, Goiás and Distrito Federal, also stood out in the national algal biodiversity scenario. Despite the shortage of taxonomists and limited infrastructure, the results showed a significant improvement in the knowledge regarding the diversity of cyanobacteria and algae in the country during the study period, starting to even out regional geographical differences caused by subsampling.
\end{abstract}

Key words: Biodiversity, phycology.

\section{Resumo}

Apresenta-se uma síntese atualizada de informações sobre algas no Brasil objetivando refinar os dados reunidos até o presente, bem como avaliar os avanços sobre o conhecimento da diversidade de algas no país desde a publicação do Catálogo de Plantas e Fungos do Brasil. Os resultados de 2015 mostraram um acréscimo de 1.250 espécies (35.7\%) a um total de 4.747 em relação a 2010. As classes mais diversas em número de espécies foram Bacillariophyceae, Conjugatophyceae, Florideophyceae, Cyanophyceae, Dinophyceae e Euglenophyceae. Bacillariophyceae e Cyanophyceae tiveram o maior acréscimo de espécies no intervalo de cinco anos. A região Sudeste e Sul foram as mais diversas, porém, as regiões Nordeste com os estados do Piauí e Sergipe e Centro-Oeste com os estados de Mato Grosso, Goiás e Distrito Federal destacaram-se no cenário da biodiversidade nacional. Apesar da escassez de taxonomistas e da infraestrutura limitada, os resultados obtidos evidenciaram um avanço significativo no conhecimento da diversidade de algas no país nesse período de cinco anos, iniciando uma mudança quanto as diferenças geográficas regionais.

Palavras-chave: Biodiversidade, ficologia.

For the complete list of authors, institutions and taxonomic groups see supplementary material <http://dx.doi.org/10.6084/m9.figshare.1531951> DOI: 10.1590/2175-7860201566408).

${ }^{1}$ Author for correspondence: menezes.mariangela@gmail.com 


\section{Introduction}

The publication of the Algae and Cyanobacteria (Bicudo \& Menezes 2010) in the Catálogo de Plantas e Fungos do Brasil (Forzza et al. 2010) represents a milestone for the phycological knowledge in the country and worldwide. Until then, there was no single compilation presenting detailed information of these organisms' diversity in different parts of Brazil. The knowledge was dispersed in regional or local lists (e.g. CordeiroMarino 1978; De-Lamonica-Freire 1989a, 1989b; Senna et al. 1998; Menezes \& Dias 2001; Oliveira et al. 2002; Torgan et al. 2003) and/or restricted to particular algal groups (p.ex. Moreira-Filho et al. 1985; Torgan et al. 1999, 2001; Alves-da-Silva \& Hahn 2001; Guimarães 2006; Tremarin et al. 2009; Procopiack et al. 2006).

Since the publication of the Catálogo de Plantas e Fungos do Brasil, several new local and regional lists focusing on specific algal groups and general catalogues were published. Diatoms of central-western Brazil (da Silva et al. 2011); Chlorophyceae of Mato Grosso (Freitas \& LoverdeOliveira 2013); cyanobacteria and continental Algae of Pará (Costa et al. 2014); deep sea macroalgae associated to rodolith beds in coastal Espírito Santo (Amado Filho et al. 2010); bentonic algae from the Laje Santos, São Paulo (Jorge et al. 2012); macroalgae in the islands off the coast of Paraná (Pellizari et al. 2014); bentonic algae from Sergipe's coast (Pereira et al. 2014); and the revised and updated checklist of macroalgae from the Abrolhos Archipelago and Sebastião Gomes reef, state of Bahia (Torrano-Silva \& Oliveira 2014a).

Numerous articles regarding new records for Brazil and descriptions of new species have also been published. Increased collecting effort, especially in deep waters, and molecular biology studies have generated valuable knowledge. DNA barcoding tecniques helped to perform more precise identifications and also led to the correction of former determinations that incurred in erroneous citations of taxa that, in fact, do not occur along the Brazilian coast. Some examples are publications by Sutherland et al. (2011), Bahia et al. (2011), Cassano et al. (2012), Carvalho et al. (2012), Alves et al. (2012), Bahia et al. (2013), Jesus et al. (2013), Pellizzari et al. (2013), Rocha-Jorge et al. (2013), Bahia et al. (2014a, 2014b), Henriques et al. (2014), Moura et al. (2014), Nauer et al. (2014a, b), Nunes et al. (2014), Torrano-Silva et al. (2014b), Jesus et al. (2015) and Lyra et al. (2015).
New occurrences and, more noticeably, the description of new taxa of microalgae were also a result of the increase in collection efforts, particularly the work regarding diatoms and cyanobacteria carried out by Wetzel et al. (2012a, b), Gama Jr. et al. (2012), Burliga et al. (2013), Caires et al. (2013), Santos et al. (2013) and Tremarin et al. (2013).

The present paper aims to present a synthesis of the updated list of Brazilian Algae based in the new records, literature and herbarium data added between 2010 and 2015. The objective was to refine and update the data initially gathered, adjusting what was published for Algae in the Brazilian Catalogue (Bicudo \& Menezes 2010) and to examine the information compiled in the Brazilian List over the past five years.

\section{Methods}

Methodology followed that published by Forzza et al. (2010). Taking the Algae list published by Bicudo \& Menezes (2010) as a starting point, new taxa and occurrences for Brazil were included in the online system together with voucher information and/or literature reference stating the presence of a given taxon in Brazil, its geographic distribution, environment and life-form.

The taxonomic status of all names was checked and nomenclatural updates followed Guiry \& Guiry (2015) and other recent relevant articles, such as Krienitz \& Bock (2012) and Gómez (2013).

Changes in class circumscription meant that previously recognized classes Prymnesiophyceae and Rhodophyceae were not featured in the 2015 version of the Brazilian List. The first was included in Coccolithophyceae, while the latter was broken down into four different classes: Bangiophyceae, Florideophyceae, Porphyriophyceae and Stylonematophyceae.

Genera Verdigellas D.L.Ballan. \& J.N.Norris and Palmophyllum Kütz. (formerly included in Ulvophyceae), Micromonas Manton \& Parke, Pseudoscourfieldia Manton and Pyramimonas Schmarda were placed in the Prasinophyceae. Partial resolution of the phylogenetic relationships of these genera was provided by Marin \& Melkonian (2009) and Fučíková et al. (2014) leading to the adoption of the 'prasinophytes' group concept, coined by Leliaert et al. (2012).

The complete dataset used for the present analyses can be found at the Brazilian List of Algae (see supplementary material $<\mathrm{http}$ ://dx.doi. 
org/10.6084/m9.figshare.1538646> - DOI: $10.1590 / 2175-7860201566408)$. This new dataset includes, as well as the Brazilian states and regions of occurrence for the taxa, the distribution by hydrographic region for the continental Algae in order to provide data for biogeographic studies and conservation strategies. Under the definition of the Brazilian National Council for Water Resources (Conselho Nacional de Recursos Hídricos - CNRH) an hydrographic region represents the territorial space comprised by a drainage basin or group of basins or sub-basins close to each other and with homogeneous or similar natural, social and economic attributes, established through Brazilian law (Resolution 32 of the CNRH, published 15/10/03). Each hydrographic region constitutes an administrative region and also a main unit for planning and management of water resources, falling under the responsibility of the CNRH. Furthermore, the integrated management of combined hydrographic basins, such as the implantation of a network of conservation units, is an example of an adequate model to select suitable conservation regions, favouring connectivity of the habitats within and between the hydrographic basins (Hero \& Hidway 2006).

Therefore, according to the CNRH (see above), Brasil is currently divided into 12 hydrographic regions: 1) Amazonian (states of Acre, Amazonas, Rondônia and Roraima, Pará, Mato Grosso and Amapá); 2) East Atlantic (Sergipe, Bahia, Minas Gerais and of Espírito Santo); 3) Northeast Occidental (Pará and Maranhão); 4) Northeast Oriental (Piauí, Ceará, Paraíba, Rio Grande do Norte, Alagoas and Pernambuco); 5) Southeast Atlantic (Minas Gerais, Espírito Santo, Rio de Janeiro, São Paulo (25\% of Southeastern Brazilian region) and Paraná); 6) South Atlantic (Paraná, Santa Catarina and Rio Grande do Sul); 7) Paraguay (Mato Grosso do Sul and Mato Grosso); 8) Paraná (São Paulo, Paraná, Mato Grosso do Sul, Minas Gerais, Goiás, Santa Catarina and Distrito Federal); 9) Parnaíba (Piauí, Maranhão and Ceará); 10) São Francisco (Minas Gerais, Distrito Federal, Goiás, Bahia, Pernambuco, Alagoas and Sergipe); 11) TocantinsAraguaia (Goiás, Tocantins, Pará, Maranhão, Mato Grosso and Distrito Federal); and 12) Uruguay (Rio Grande do Sul and Santa Catarina).

\section{Results}

The analysis of the 2015 Brazilian List of Algae (see supplementary material <http:// dx.doi.org/10.6084/m9.figshare.1538646> - DOI:
$10.1590 / 2175-7860201566408)$ shows the algae and cyanobacteria diversity divided in 29 classes, 1,018 genera, 4,747 species, 12 subspecies and 1,424 varieties. The Incertae sedis category was added in 2014 to include taxa referred for Brazil in 19th century publications for which the systematic positioning remains unsure (39 species). When compared with the data from 2010 (Fig. 1) an increase of 1,711 taxa, 12 classes, 189 genera, 1,250 species, four subspecies and 457 varieties. Of these, 33 are new taxa described for Brazil by a total of 48 Brazilian researchers in the following groups: Cyanophyceae (13), Bacillariophyceae (12), Florideophyceae (11), Conjugatophyceae (four), Trebouxiophyceae (three), Florideophyceae (nine), Bangiophyceae (three), Ulvophyceae (seven) (Tab. 1).

The ten most diverse classes were: Bacillariophyceae with 1,247 species, followed by the Conjugatophyceae (610), Florideophyceae (489), Cyanophyceae (462), Dinophyceae (420), Euglenophyceae (367), Chlorophyceae (352), Ulvophyceae (217), Phaeophyceae (103) and Coccolithophyceae (91). There were no changes regarding the diversity of classes Chrysophyceae, Cryptophyceae, Dictyocophyceae, Raphidophyceae, Synurophyceae and Xanthophyceae. On the other hand, a drop in the number of taxa in the

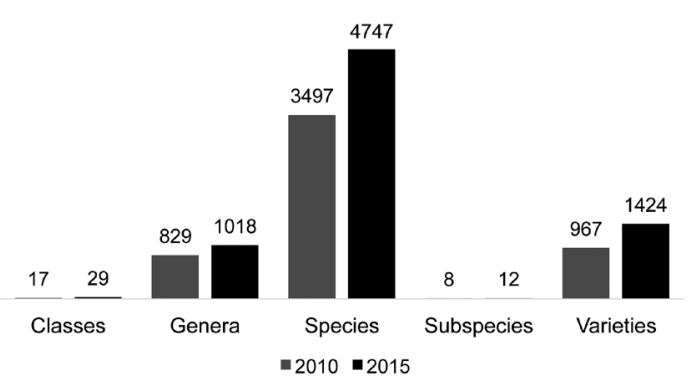

Figure 1 - Number of algae and cyanobacteria for Brazil distributed by taxonomic levels in 2010 and 2015.

Table 1 - Distribution of the number of new species of algae and cyanobacteria described by their publishing Brazilian authors between 2010 and 2015.

\begin{tabular}{ll}
\hline Number of new species & Number of authors \\
\hline$\geq 7$ & 2 \\
$3-4$ & 3 \\
$1-2$ & 43 \\
\hline
\end{tabular}


Table 2 - Number of algae and cyanobacteria genera and species recorded in 2010 and 2015, distributed by class. (-) Not included in 2010 or 2015; (*) - Included in Coccolithophyceae in 2014; (**) - subdivided in 2015 in Bangiophyceae, Compsopogonophyceae, Florideophyceae, Porphyriophyceae and Stylonematophyceae. GEN: genera, SP: species.

\begin{tabular}{|c|c|c|c|}
\hline \multirow{2}{*}{ Classes } & \multirow{2}{*}{ Categorias } & \multicolumn{2}{|c|}{ Ano } \\
\hline & & 2010 & 2015 \\
\hline \multirow{2}{*}{ Bacillariophyceae } & GEN & 163 & 211 \\
\hline & SP & 888 & 1247 \\
\hline \multirow{2}{*}{ Charophyceae } & GEN & 35 & 3 \\
\hline & SP & 419 & 59 \\
\hline \multirow{2}{*}{ Chlorophyceae } & GEN & 88 & 75 \\
\hline & SP & 319 & 352 \\
\hline \multirow{2}{*}{ Cyanophyceae } & GEN & 89 & 132 \\
\hline & $\mathrm{SP}$ & 208 & 462 \\
\hline \multirow{2}{*}{ Dinophyceae } & GEN & 65 & 82 \\
\hline & SP & 374 & 420 \\
\hline \multirow{2}{*}{ Euglenophyceae } & GEN & 20 & 29 \\
\hline & SP & 311 & 367 \\
\hline \multirow{2}{*}{ Phaeophyceae } & GEN & 48 & 49 \\
\hline & SP & 94 & 103 \\
\hline \multirow{2}{*}{ Prasinophyceae } & GEN & 8 & 5 \\
\hline & SP & 15 & 11 \\
\hline \multirow{2}{*}{ Ulvophyceae } & GEN & 49 & 54 \\
\hline & SP & 170 & 217 \\
\hline \multirow{2}{*}{ Chrysophyceae } & GEN & 17 & 17 \\
\hline & SP & 43 & 43 \\
\hline \multirow{2}{*}{ Cryptophyceae } & GEN & 9 & 9 \\
\hline & SP & 35 & 34 \\
\hline \multirow{2}{*}{ Dictyocophyceae } & GEN & 2 & 2 \\
\hline & SP & 4 & 4 \\
\hline \multirow{2}{*}{ Raphidophyceae } & GEN & 6 & 6 \\
\hline & SP & 9 & 9 \\
\hline \multirow{2}{*}{ Synurophyceae } & GEN & 3 & 3 \\
\hline & SP & 42 & 42 \\
\hline \multirow{2}{*}{ Xanthophyceae } & GEN & 28 & 28 \\
\hline & SP & 71 & 72 \\
\hline \multirow{2}{*}{ Bangiophyceae } & GEN & - & 3 \\
\hline & SP & - & 7 \\
\hline
\end{tabular}




\begin{tabular}{|c|c|c|c|}
\hline \multirow{2}{*}{ Classes } & \multirow{2}{*}{ Categorias } & \multicolumn{2}{|c|}{ Ano } \\
\hline & & 2010 & 2015 \\
\hline \multirow{2}{*}{ Chlorodendrophyceae } & GEN & - & 2 \\
\hline & SP & - & 2 \\
\hline \multirow{2}{*}{ Coccolithophyceae } & GEN & - & 49 \\
\hline & SP & - & 91 \\
\hline \multirow{2}{*}{ Coleochaetophyceae } & GEN & - & 1 \\
\hline & SP & - & 3 \\
\hline \multirow{2}{*}{ Compsopogonophyceae } & GEN & - & 4 \\
\hline & SP & - & 5 \\
\hline \multirow{2}{*}{ Conjugatophyceae } & GEN & - & 44 \\
\hline & SP & - & 610 \\
\hline \multirow{2}{*}{ Florideophyceae } & GEN & - & 174 \\
\hline & SP & - & 489 \\
\hline \multirow{2}{*}{ Klebsormidiophyceae } & GEN & - & 1 \\
\hline & SP & - & 5 \\
\hline \multirow{2}{*}{ Mamiellophyceae } & GEN & - & 1 \\
\hline & SP & - & 1 \\
\hline \multirow{2}{*}{ Nephroselmidophyceae } & GEN & - & 1 \\
\hline & SP & - & 3 \\
\hline \multirow{2}{*}{ Pedinophyceae } & GEN & - & 2 \\
\hline & SP & - & 2 \\
\hline \multirow{2}{*}{ Porphyridiophyceae } & GEN & - & 1 \\
\hline & SP & - & 2 \\
\hline \multirow{2}{*}{ Stylonematophyceae } & GEN & - & 3 \\
\hline & SP & - & 4 \\
\hline \multirow{2}{*}{ Prymnesiophyceae* } & GEN & 46 & - \\
\hline & SP & 93 & - \\
\hline \multirow{2}{*}{ Rhodophyceae* } & GEN & 153 & - \\
\hline & SP & 402 & - \\
\hline
\end{tabular}

Charophyceae followed the exclusion of the Desmidiaceae, nowadays considered as part of the Conjugatophyceae. The Rodophyceae were increased by 36 genera and 111 species. The classes that saw the largest increases in species numbers in 2015 were the Bacillariophyceae and the Cyanophyceae (Tab. 2).
In terms of epicontinental or marine environment, eleven classes are exclusively epicontinental (Charophyceae, Chlorodendrophyceae, Chlorophyceae, Coleochaetophyceae, Conjugatophyceae, Klebsormidiophyceae, Mamiellophyceae, Porphyridiophyceae, Synurophyceae, 
Trebouxiophyceae and Xanthophyceae), six are exclusively marine (Coccolithophyceae, Bangiophyceae, Dictyochophyceae, Prasinophyceae, Phaeophyceae and Stylonematophyceae), while the remaining 13 classes occur in both environments (Tab. 3).

Algae and cyanobacteria distribution by Brazilian geopolitical regions is shown in Figure 2. When compared to the 2010 data, the new data show an increase in the number of taxa in all regions with Southeast Brazil as the most diverse, followed by South, Northeast, Centralwest and Northern. When we analyse the state records, only Amapá, Acre, Roraima, Rondônia and Tocantins did not show expressive increase in species numbers from 2010 to 2015 (Tab. 4). The states with the higher increase in number of taxon records were Mato Grosso and Piauí, where the records were respectively $81 \%$ and $79 \%$ higher, followed by Sergipe, with $54 \%$, Goiás $50 \%$ and Distrito Federal with $40 \%$. Despite the increases, species distribution between the states and the geopolitical regions continued to be heterogeneous (Fig. 3).

Taking into account only the macroalgae and marine cyanobacteria (Fig. 4), number of species per class continued to be higher in the southeast and northeast regions. Excepting Cyanophycae and macroscopic Prasinophyceae, 762 species of red, brown and green algae were recorded in 2015 , amounting to $12.6 \%$ more than found in 2010. The states where the marine macroalgae have shown higher number of species were the same found by Bicudo \& Menezes (2010), namely Espírito Santo, Rio Janeiro, Bahia, São Paulo, Pernambuco and Rio Grande do Norte, and the ones where the species number increased more

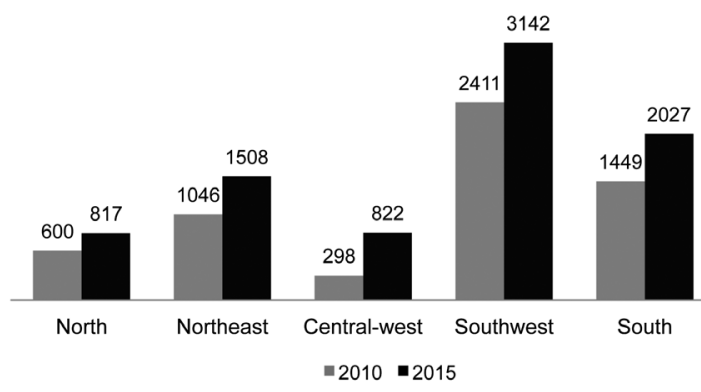

Figure 2 - Number of epicontinental algae and cyanobacteria taxa distributed by Brazilian geopolitical region in 2010 and 2015. markedly were Rio Grande do Norte (91), Bahia (87), Espírito Santo (79), Sergipe (75), São Paulo (71) and Pernambuco (63) (Tab. 5).

Regarding marine cyanobacteria, 2015 saw 73 species while in 2010 there were only 17 recorded for Brazil, and the state with higher number of species was São Paulo (63), followed by Rio de Janeiro (26), Bahia (23) and Rio Grande do Sul (16). Other states such as Pará, Maranhão, Ceará, Rio Grande do Norte, Espírito Santo, Paraná and Santa Catarina have.

There were no changes in the number of species or the distribution of Verdigellas and Palmophyllum (Prasinophyceae) between 2010 and 2015, with the species distribution being restricted to deep environments off the coast of Bahia, Espírito Santo and Rio de Janeiro (Tab. 5).

The marine microalgae (Tab. 3) had an increase of 251 species $(1,175$ in 2015 vs. 924 in 2010). The states with the largest growth in the number of records were Paraná $(37 \%)$, Pernambuco (32\%), Rio de Janeiro (29\%), Pará (27\%), Rio Grande do Sul (25\%), Espírito Santo $(21 \%)$ and Bahia (21\%). The remaining states had inexpressive alterations on the number of taxa, growing up to $16 \%$, e.g. Bahia, Alagoas, Sergipe, Piauí and Amazonas had records equal or lower than five taxa. South and Northeast regions continued to be the most diverse, while, at state level, São Paulo (549 species), Rio Grande do Sul (529 species), Rio de Janeiro (491 species), Paraná (364 species), Pernambuco (348 species) and Bahia (303) are the leading states. The Bacillariophyceae and Dinophyceae continued to be the microalgae classes with the highest number of taxa (Tab. 6).

Epicontinental algae (Tab. 3) have reached 2,808 species records in 2015, an additional 918 species to the 2010 figure of 1,890 . Central-west, South, and Southeast regions have had the highest species number increases since 2010, followed by Northeast and North. The states of Bahia (85\%), Minas Gerais (42\%), Goiás (38.3\%), Amazonas (28.2\%), Distrito Federal (27\%), Mato Grosso (25\%) and Paraná (24\%) had the highest species number increases. The most diverse states in terms of species numbers were Rio de Janeiro, São Paulo, Paraná, Rio Grande do Sul, Amazonas, Mato Grosso, Goiás, Distrito Federal and Bahia. The most diverse group continues to be the Bacillariophyceae followed by Conjugatophyceae (formerly included in the Charophyceae), Euglenophyceae and Chlorophyceae (Tab. 6). 
Cyanobacteria species number added up to 389 in 2015 from a total of 294 in 2010, and the regions with highest increase in records were the Southeast and South (83\% each), and the Central-western (53.5\%). At state level, São Paulo (48.2\%), Rio de Janeiro (42\%), Rio Grande do Sul (42\%), Amazonas (37.2\%) and Distrito Federal (31.4\%) have shown the largest increase in specie records (Tab. 3, Tab. 6). São Paulo, Rio de Janeiro and Rio Grande do Sul feature as the most diverse states in terms of number of taxa (Tab. 6).

Amongst the 1,018 genera currently recognized in 2015, 41 (4\%) concentrate 1,852 (39\%) of the species listed (Tab. 7). The four genera with largest number of taxa were Cosmarium Corda ex Ralfs (Conjugatophyceae) with 156 species, Pinnularia Ehrenb. (Bacillariophyceae) with 125, Trachelomonas Ehrenb. (Euglenophyceae) with 107 and Staurastrum Meyen ex Ralfs (Conjugatophyceae), with 93 species.

Regarding the occurrence of algae and cyanobacteria by hydrographic region (Fig. 5), the most representative were the Southeast Atlantic and Paraná, followed by the South Atlantic and the Amazonian Hidrographic Regions. The lowest number of records was found in the Northeast Occidental Atlantic and Parnaíba regions, which are also less well known territories in terms of their algal biodiversity.

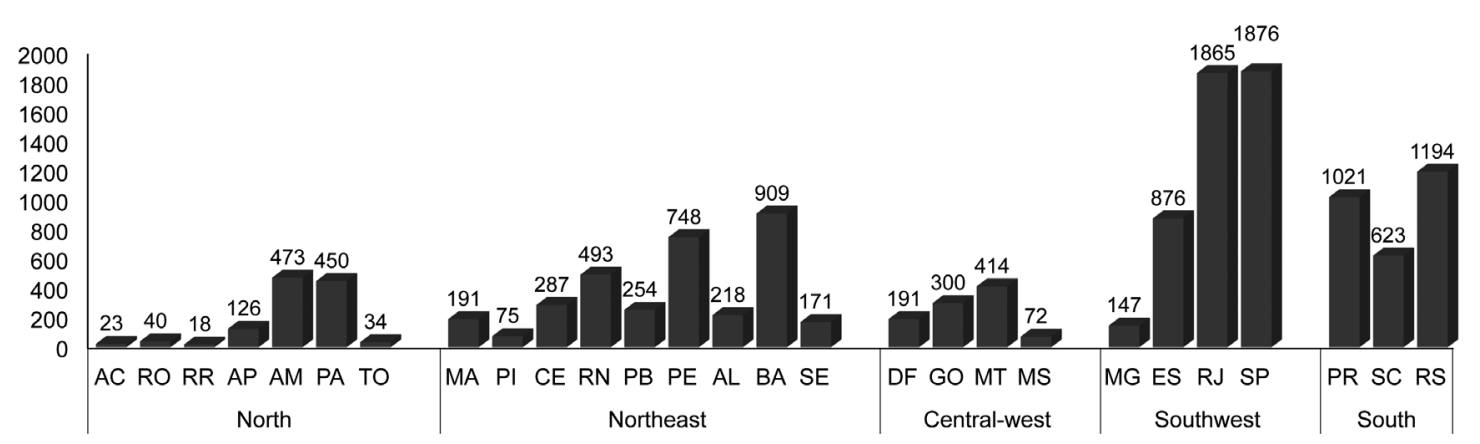

Figure 3 - Number of algae and cyanobacteria species distributed by state and Brazilian geopolitical region.

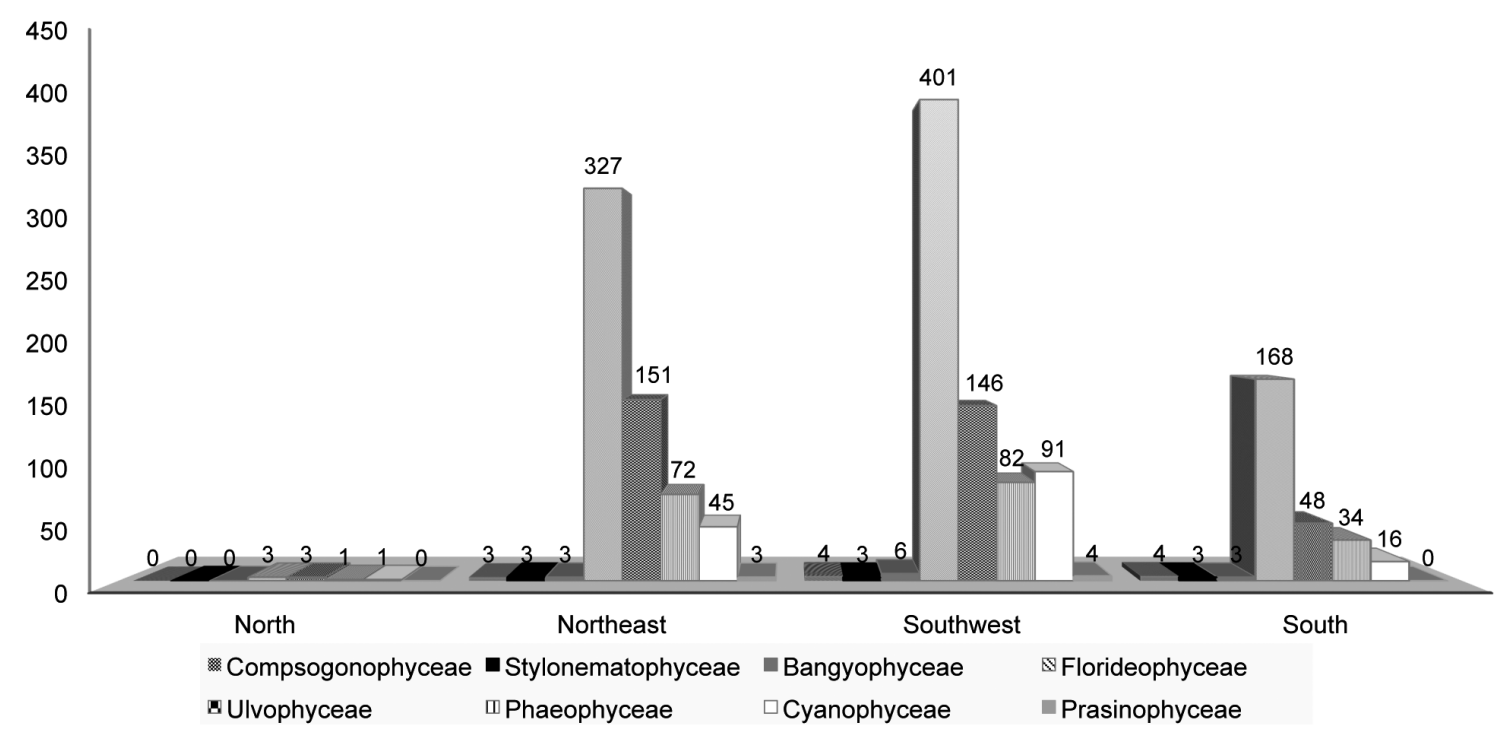

Figure 4 - Seaweeds and marine cyanobacteria species richness distributed by Brazilian geopolitical region and taxonomic class. 
Table 3 - Species richness of algae and cyanobacteria classes recorded in 2010 and 2015, distributed by environment. (*) Updates of the data published in 2010; (-) - Not included in 2010; (**) - Including Conjugatophyceae taxa; (1) previously included in Rhodophyceae; (2) - including 2010 Prymnesiophyceae taxa.

\begin{tabular}{|c|c|c|c|c|}
\hline \multirow{3}{*}{ Classes } & \multicolumn{4}{|c|}{ Ambiente } \\
\hline & \multicolumn{2}{|c|}{ Epicontinental } & \multicolumn{2}{|c|}{ Marinho } \\
\hline & $2010^{*}$ & 2015 & $2010 *$ & 2015 \\
\hline Bacillariophyceae & 424 & 645 & 464 & 601 \\
\hline Bangiophyceae $^{1}$ & - & 0 & - & 7 \\
\hline Charophyceae & $419 * *$ & 50 & 0 & 0 \\
\hline Chlorodendrophyceae & - & 2 & - & 0 \\
\hline Chlorophyceae & 319 & 358 & 0 & 0 \\
\hline Chrysophyceae & 39 & 43 & 4 & 3 \\
\hline Coccolithophyceae $^{2}$ & 2 & 0 & 91 & 91 \\
\hline Coleochaetophyceae & - & 3 & - & 0 \\
\hline Compsopogonophyceae $^{1}$ & - & 1 & - & 4 \\
\hline Conjugatophyceae & - & 610 & - & 0 \\
\hline Cryptophyceae & 35 & 31 & - & 3 \\
\hline Cyanophyceae & 191 & 389 & 17 & 73 \\
\hline Dictyocophyceae & & 0 & 4 & 4 \\
\hline Dinophyceae & 27 & 37 & 347 & 384 \\
\hline Euglenophyceae & 309 & 365 & 2 & 2 \\
\hline Florideophyceae $^{1}$ & - & 25 & - & 464 \\
\hline Klebsormidiophyceae & - & 5 & - & 0 \\
\hline Mamiellophyceae & - & 1 & - & 0 \\
\hline Nephroselmidophyceae & - & 2 & - & 1 \\
\hline Pedinophyceae & 0 & 1 & 0 & 1 \\
\hline Phaeophyceae & 0 & 0 & 94 & 103 \\
\hline Porphyridiophyceae $^{1}$ & - & 2 & - & 0 \\
\hline Prasinophyceae & 6 & 0 & 9 & 11 \\
\hline Raphidophyceae & 6 & 6 & 3 & 3 \\
\hline Stylonematophyceae $^{1}$ & - & 0 & - & 4 \\
\hline Synurophyceae & 42 & 42 & 0 & 0 \\
\hline Trebouxiophyceae & 0 & 81 & 0 & 0 \\
\hline Ulvophyceae & 0 & 37 & 170 & 180 \\
\hline Xanthophyceae & 71 & 72 & 0 & 0 \\
\hline Total & 1890 & 2808 & 1205 & 1939 \\
\hline
\end{tabular}




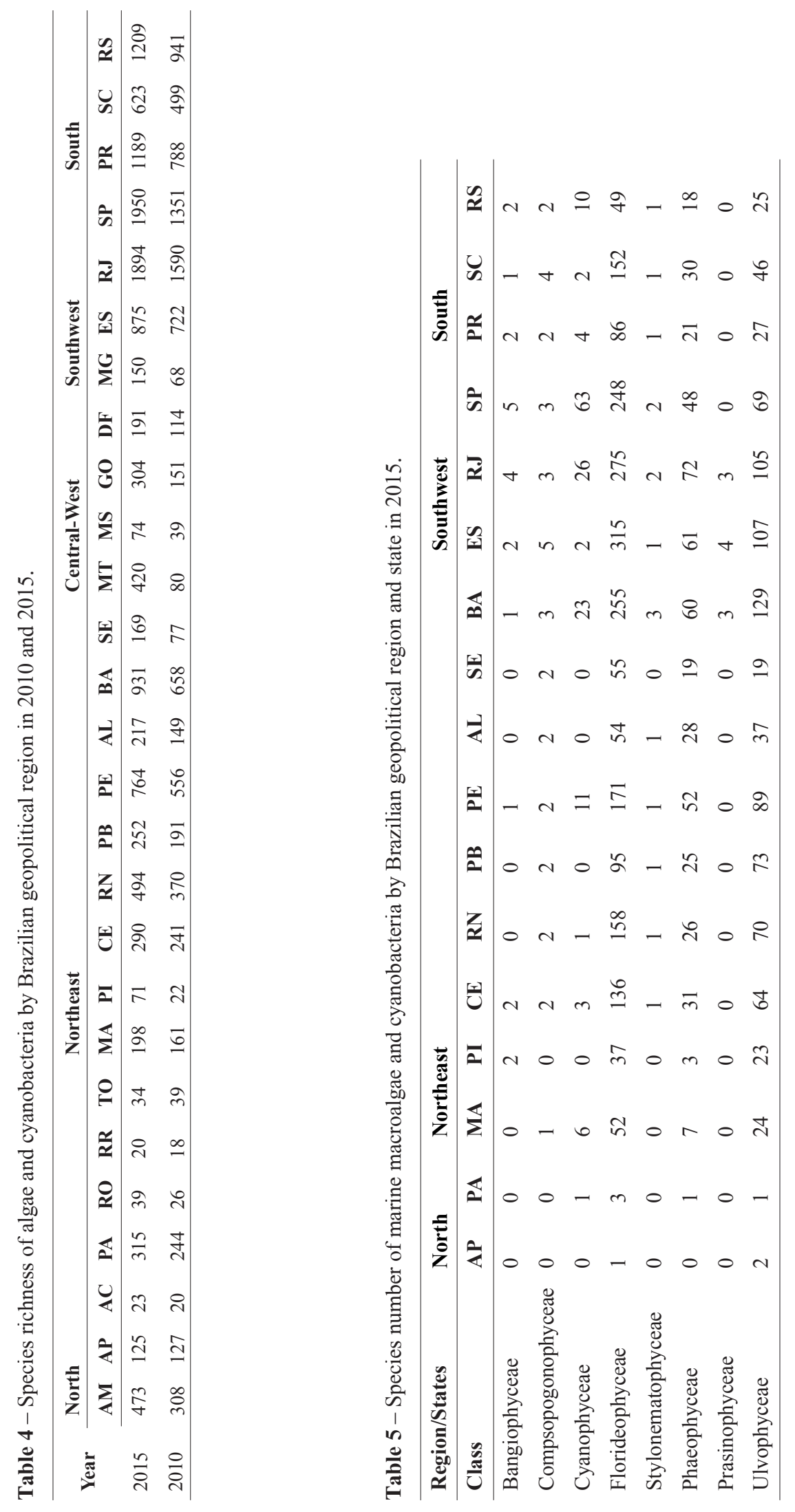




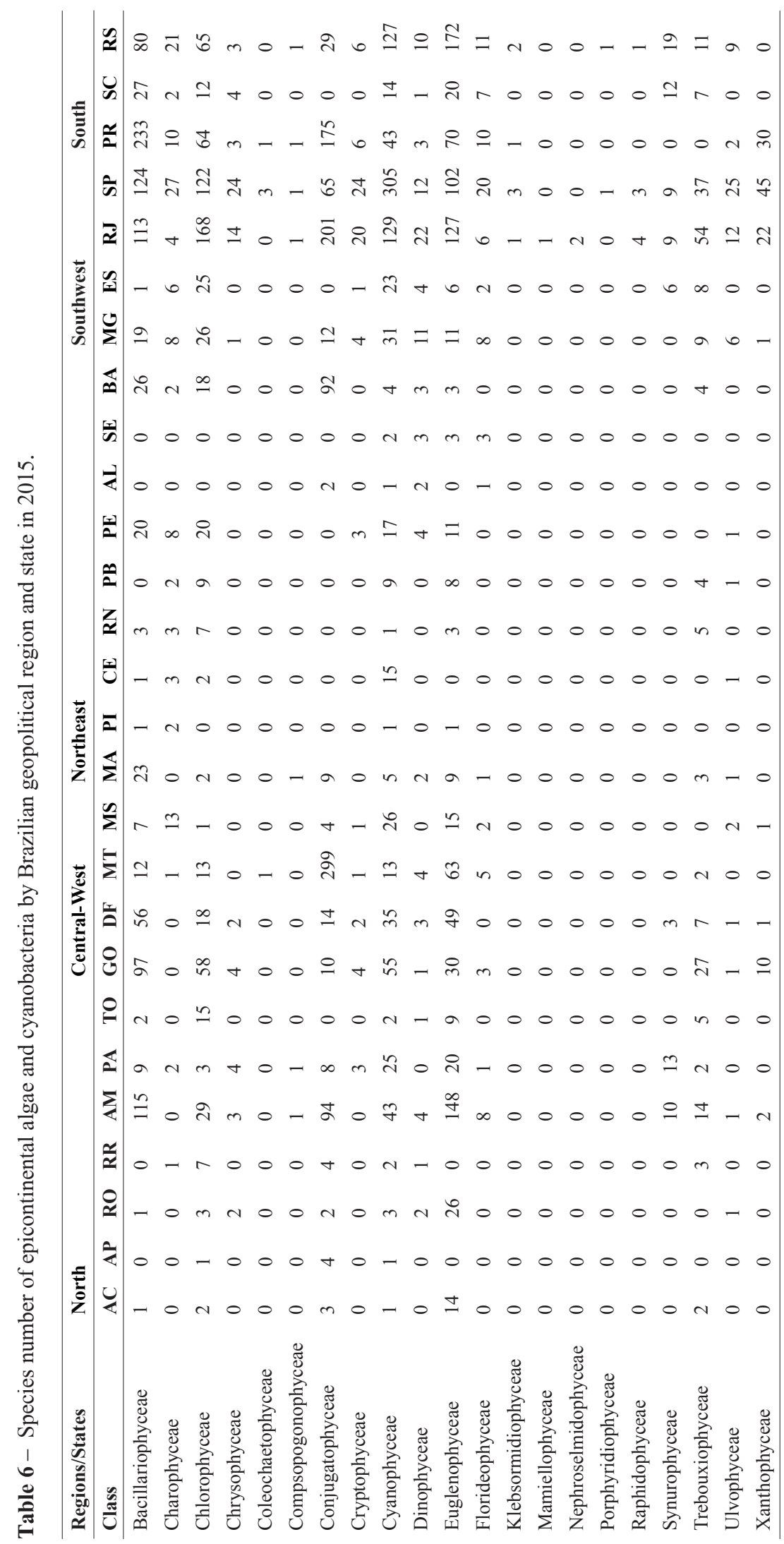


Table 7 - Species number of the most species rich genera of algae and cyanobacteria recorded in Brazil in 2015.

\begin{tabular}{|c|c|c|}
\hline Class & Genus & Species number \\
\hline Conjugatophyceae & Cosmarium & 156 \\
\hline Bacillariophyceae & Pinnularia & 125 \\
\hline Euglenophyceae & Trachelomonas & 107 \\
\hline Conjugatophyceae & Staurastrum & 93 \\
\hline Bacillariophyceae & Eunotia & 72 \\
\hline Euglenophyceae & Phacus & 69 \\
\hline Dinophyceae & Protoperidinium & 66 \\
\hline Chlorophyceae & Oedogonium & 65 \\
\hline Bacillariophyceae & Navicula & 63 \\
\hline Conjugatophyceae & Closterium & 60 \\
\hline Dinophyceae & Tripos & 56 \\
\hline Bacillariophyceae & Chaetoceros & 50 \\
\hline Euglenophyceae & Strombomonas & 48 \\
\hline Conjugatophyceae & Spirogyra & 47 \\
\hline Conjugatophyceae & Euastrum & 47 \\
\hline Bacillariophyceae & Nitzschia & 46 \\
\hline Bacillariophyceae & Surirella & 41 \\
\hline Euglenophyceae & Euglena & 39 \\
\hline Bacillariophyceae & Amphora & 36 \\
\hline Dinophyceae & Dinophysis & 35 \\
\hline Synurophyceae & Mallomonas & 33 \\
\hline Cyanophyceae & Phormidium & 32 \\
\hline Conjugatophyceae & Micrasterias & 31 \\
\hline Conjugatophyceae & Staurodesmus & 29 \\
\hline Bacillariophyceae & Coscinodiscus & 28 \\
\hline Euglenophyceae & Lepocinclis & 28 \\
\hline Euglenophyceae & Entosiphon & 28 \\
\hline Chlorophyceae & Chlamydomonas & 27 \\
\hline Charophyceae & Nitella & 27 \\
\hline Bacillariophyceae & Diploneis & 25 \\
\hline Chlorophyceae & Scenedesmus & 25 \\
\hline Ulvophyceae & Cladophora & 24 \\
\hline Conjugatophyceae & Pleurotaenium & 23 \\
\hline Charophyceae & Chara & 23 \\
\hline Ulvophyceae & Caulerpa & 22 \\
\hline Cyanophyceae & Scytonema & 22 \\
\hline Dinophyceae & Oxytoxum & 22 \\
\hline Bacillariophyceae & Gyrosigma & 21 \\
\hline Bacillariophyceae & Cocconeis & 21 \\
\hline Dinophyceae & Gymnodinium & 21 \\
\hline Florideophyceae & Ceramium & 19 \\
\hline Total & & 1852 \\
\hline
\end{tabular}




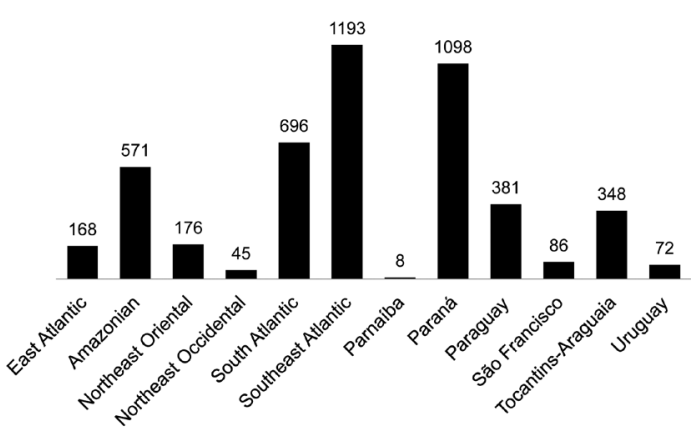

Figure 5 - Species richness of epicontinental algae and cyanobacteria by Brazilian hydrographic region

\section{Discussion}

The number of records $(1,250)$ added to the latest version of the Algae and Cyanobacteria (Bicudo \& Menezes 2010) represents another important advancement for neotropical phycology, however we believe that there is still much research to be carried out. The present total of 4,747 species recorded for different environments and Brazilian states is becoming close to previous estimates by Bicudo et al. (1998) and Menezes \& Bicudo (2009), of respectively 5,000 and 5,614 species. These estimates are still fairly distant from the real algal diversity to be found in the country, when the extense geographic gaps that have not been studied are taken into account. Some taxonomic groups have been subestimated as it is obviated below.

Using the cyanobacteria as an example, taking worldwide figures of 5,000 known species and 3,000 species still to be described estimated by Guiry (2012), the 462 cyanobacteria species currently recorded for Brazil represent less than $10 \%$ of the known species, or slightly more than $5 \%$ of the total estimated. However Rocha (2006) estimated that there would be around 1,200 species in this group, and the figure recorded so far for Brazil is around $38 \%$ of this estimate.

Of the new species of cyanobacteria and microalgae included in the Brazilian List between 2010 and 2015, seven belong to genus Brasilonema Fiore et al. (Sant'Anna et al. 2011), one of each Scytonema C.Agardh ex Bornet \& Flahault (Hentschke \& Komarék 2014), Lemmermaniella Geitler (Gama Jr. et al. 2014), Chroococcus Nägeli (Gama Jr et al. 2014) and Eunotia Ehrenb. (Furhmann et al. 2013) for the Paraná hydrographic region, São Paulo state.
A species of Symploca Kütz. ex Gomont was described for coastal Bahia (Caires et al. 2013).

One species of Urosolenia Round \& R.M.Crawford (Tremarin et al. 2013a) and two Encyonema Kütz. (da Silva et al. 2015) were described for For the Paraná hydrographic region while a species of Conjugatophyceae, Staurastrum Meyen ex Ralfs (Santos et al. 2013) and a Cyanophyceae belonging to the genus Pannus Hickel (Malone et al. 2014) were described for the Paraguay hydrographic region (pantanal of Nhecolândia, Mato Grosso do Sul state). For the Amazon hydrographic region the monotypic new genera Eunotioforma Kociolek \& Burliga and Bicudoa C.E.Wetzel et al. (Wetzel et al. 2012a; Burliga et al. 2013), as well as a species of Tursiocola R.W.Holmes et al. (Wetzel et al. 2012b) and another of Aulacoseira Thwaites (Tremarin et al. 2013b) were described. A new species of Oocystis A.Braun (Ramos et al. 2015) was described from the West Atlantic hydrographic region. Three new species of Diatomaceae (one Eunotia and two Aulacoseira) described have wider distribution and span through two or more hydrographic regions (Metzeltin \& Tremarin 2011; Tremarin et al. 2012; Tremarin et al. 2014).

Regarding marine macroalgae, genus Laurenciella Cassano et al. (Florideophyceae) was proposed with basis on molecular evidence (Cassano et al. 2012), while four species of Hypnea J.V.Lamour. (Nauer et al. 2014a, b; Jesus et al. 2015), one of Osmundea Stackh. (Rocha-Jorge et al. 2013) and two Ulvophyceae, Codium pernambucensis Oliveira \& S.M.B.Pereira (Carvalho et al. 2012) and Gayralia brasiliensis Pellizari et al. (Pellizzari et al. 2013) were described during the last five years.

The Bacillariophyceae and the Florideophyceae are the most speciose groups of respectively microalgae and macroalgae, both showing an increase in species number during the last period, while the records of other groups, considered underestimated already in 2010 (Bicudo \& Menezes 2010), such as Coccolithophyceae, Prasinophyceae and Xanthophyceae, remain unaltered.

The number (33) of new species described for Brazil during the 2010-2015 period means that around six species were described per year. When analysing the authors against the new species described, we found that the number of new species dividided by the number of Brazilian authors (48), gives a proportion close to one (0.7) over the last 
five years. However, the breakdown of species described per authors is heterogeneous (Tab. 1), showing that the productivity is concentrated by a handful of taxonomists with enough experience and/or access to the collections needed to perform this task. This highlights the insufficiency of specialized, well trained researchers able to describe the overwhelming diversity of organisms found in Brazil. On the other hand, according to Sangster \& Luksenburg (2015), a new trend of increased time and effort employed by taxonomists to produce good quality, complete new descriptions implies in less frequent subsequent revisions of taxonomic concepts. Studies suggest that, while new taxa continue to be described at a steady rate, the number of taxonomists has actually increased (Pimm et al. 2010; Jope et al. 2011; Tancoigne $\&$ Dubois 2013) therefore the number of species described per taxonomist has decreased. Such studies conclude that the number of taxonomy researchers is not declining, proposing that the decline seen is in the productivity per taxonomist (Sangster \& Luksenburg 2015).

Summarizing, our results show an increase in the knowledge regarding algal biodiversity in Brazil during the last five years that has started to close the gap between better studied and less known regions. Even with Southeast and South regions maintaining their position as the most diverse areas through our better understanding of their algal flora (Bicudo \& Menezes 2010), the present records for some states within the Northeast, such as Piauí and Sergipe, and the Central-western states of Mato Grosso, Goiás and Distrito Federal have shown that they also hold considerable algal biodiversity. However relatively modest, the discovery of new genera and species has increased and spread through the less known regions such as the Amazon, Northeast and Central-western.

As seen for other biodiverse countries, increased rate of description of new taxa started to address the geographic bias caused by the polarization of taxonomic research in and around the largest economic centres worldwide (Tancoigne et al. 2011; Grieneisen et al. 2014 ). On the other hand, in the case of algae and cyanobacteria, Brazil continues to face obstacles for the advancement in the knowledge of phycological diversity, be it because of global issues, such as the shortage of taxonomists specializing in this area (Guiry 2012; De Clerck et al. 2013) or, in the regional scale, such as the lack of laboratory facilities and nonavailability of biological collections where the diversity is higher (Grieneisen et al. 2014). Strategic policies have already been launched by the Brazilian government in order to accelerate the study of the country's biodiversity, however, these need to be strengthened and widened to ensure its mapping is more homogeneous and complete.

\section{Acknowledgements}

We would like to thank the coordinators of the Brazilian Floristic List for their support of the updating of the online list. To Daniela Zappi and the two anonymous reviewers for helpful comments and suggestions to the manuscript.

\section{References}

Alves, A.M.; Gestinari, L.M.S.; Oliveira, I.S. MonizBrito, K.L. \& Moura, C.W.N. 2012. The genus Cladophora (Chlorophyta) in the littoral of Bahia, Brazil. Nova Hedwigia 95: 337-372.

Alves-Da-Silva, S.M. \& Hahn, A.T. 2001. Lista das Euglenophyta registradas em ambientes de águas continentais e costeiras do Estado deo Rio Grande do Sul, Brasil. Iheringia, Série Botânica 55: 171-188.

Amado Filho, G.M.; Maneveldt, G.; Pereira Filho, G.; Manso, R.C.; Bahia, R.; Barreto, M.B.B. \& Guimaraes, S.M.P.B. 2010. Seaweed diversity associated with a Brazilian tropical rhodolith bed. Ciencias Marinas 36: 371-391.

Bahia, R.G.; Riosmena-Rodriguez, R.; Maneveldt, G.W. \& Amado Filho, G.M. 2011. Research note: First report of Sporolithon ptychoides (Sporolithales, Corallinophycidae, Rhodophyta) for the Atlantic Ocean. Phycological Research 59: 64-69.

Bahia, R.G.; Amado-Filho, G.M.; Maneveldt, G.W.; Adey, W.H.; Johnson, G.; Marins, B.V. \& Longo, L.L. 2013. Sporolithon tenue sp. nov. (Sporolithales, Corallinophycidae, Rhodophyta): A new rhodolithforming species from the tropical southwestern Atlantic. Phycological Research 62: 44-54.

Bahia, R.G.; Amado Filho, G.M. \& Maneveldt, G.W. 2014a. Sporolithon molle (Heydrich) Heydrich (Sporolithales, Corallinophycidae, Rhodophyta): An addition to the atlantic flora found on a remote oceanic island. Cryptogamie. Algologie 35:7-14.

Bahia, R.G.; Amado Filho, G.M.; Azevedo, J. \& Maneveldt, G.W. 2014b. Porolithon improcerum (Porolithoideae, Corallinaceae) and Mesophyllum macroblastum (Melobesioideae, Hapalidiaceae): new records of crustose coralline red algae for the Southwest Atlantic Ocean. Phytotaxa 190: 38-44

Bicudo, C.E.M.; Sant'Anna, C.L.; Bicudo, D.C.; Pupo, D.; Castro-Pinto, L.S.; Azevedo, M.T.P.; Xavier, M.B.; Fujii, M.T.; Yokoya, N.S. \& Guimarães, S.M.P.B. 1998. O estudo das algas no Estado de São Paulo. In: Bicudo, C.E.M. \& Shepherd, G.J. (eds.). 
Biodiversidade do Estado de São Paulo: síntese do conhecimento ao final do século XX, 2: fungos macroscópicos e plantas. Fundação de Amparo à Pesquisa do Estado de São Paulo, São Paulo. Pp 1-7.

Bicudo, C.E.M. \& Menezes, M. 2010. Algas do Brasil. In: Forzza et al. (org.). Catálogo de Plantas e Fungos do Brasil. Vol. 1. Jardim Botânico do Rio de Janeiro, Rio de Janeiro. Pp 49-61.

Burliga, A.L.; Kociolek, J.P.; Salomoni, S.E. \& Figueiredo, D. 2013. A new genus and species in the diatom family Eunotiaceae Kützing (Bacillariophyceae) from the Amazonian hydrographic region, Brazil. Phytotaxa 79: 47-57.

Caires, T.A.; Sant'anna, C.L. \& de Castro Nunes, J.M. 2013. A new species of marine benthic cyanobacteria from the infralittoral of Brazil: Symploca infralitoralis sp. nov. Brazilian Journal of Botany 36: 159-163.

Carvalho, M.F.O.; Oliveira, M.C.; Pereira, S.M.B. \& Verbruggen, H. 2012. Phylogenetic analysis of Codium species from Brazil, with the description of the new species C. pernambucensis (Bryopsidales, Chlorophyta). European Journal of Phycology 47: 355-365.

Cassano, V.; Oliveira, M.C.; Gil-Rodríguez, M.C.; Sentíes, A; Díaz-Larrea, J. \& Fujii, M.T. 2012. Molecular support for the establishment of the new genus Laurenciella within the Laurencia complex (Ceramiales, Rhodophyta). Botanica Marina 55: 349-357.

Cordeiro-Marino, M. 1978. Rodofíceas bentônicas marinhas do Estado de Santa Catarina. Rickia 7: $1-243$.

Costa, S.D.; Silva, R.C.V.M.; Bicudo, C.E.M., Barros, K.D.N. \& Oliveira, M.E.C. 2014. Algas e Cyanophyceae continentais no estado do Pará, Brasil. Embrapa, Brasília. 251p.

da Silva, W.J.; de Souza Nogueira, I. \& Souza, M.D.G. M. 2011. Catálogo de diatomáceas da região CentroOeste brasileira. Iheringia, Série Botânica 66: 61-86.

da Silva, W.J. \& de Souza, M.D.G.M. 2015. New species of the genus Encyonema (Cymbellales, Bacillariophyta) from the Descoberto River Basin, Central-western Brazil. Phytotaxa 195: 154-162.

De Clerck, O.; Guiry, M.D.; Leliaert, F.; Samyn, Y. \& Verbruggen, H. 2013. Algal taxonomy: a road to nowhere? Journal of Phycology 49: 215-225.

De-Lamônica-Freire, E.M. 1989a. Catálogo das algas referidas para o Estado de Mato Grosso, Brasil, 1. Revista Brasileira de Biologia 49: 671-677.

De-Lamônica-Freire, E.M. 1989b. Catálogo das algas referidas para o Estado de Mato Grosso, Brasil, 2. Revista Brasileira de Biologia 49: 679-689.

Forzza, R.C.; Baumgratz, J.F.A.; Bicudo, C.E.M.; Canhos, D.A.L.; Carvalho Jr., A.A.; Costa, A.F.; Costa, D.P.; Hopkins, M.; Leitman, P.M.; Lohmann,
L.G.; Maia, L.C.; Martinelli, G.; Menezes, M.; Morim, M.P.; Nadruz-Coelho, M.A.; Peixoto, A.L.; Pirani, J.R.; Prado, J.; Queiroz, L.P.; Souza, V.C.; Stehmann, J.R.; Sylvestre, L.; Walter, B.M.T. \& Zappi, D. (eds.). 2010. Catálogo de plantas e fungos do Brasil. 2 vols. Andrea Jakobsson Estúdio/Jardim Botânico do Rio de Janeiro, Rio de Janeiro. 1699p.

Freitas, L.C. \& Loverde-Oliveira, S.M. 2013. Checklist of green algae (Chlorophyta) for the state of Mato Grosso, Central Brazil. Check List 9: 1471-1483.

Fučíková, K.; Leliaert, F.; Cooper, E.D.; Škaloud, P.; D'Hondt, S.; De Clerck, O.; Gurgel, C.F.D.; Lewis, L.A.; Lewis, P.; Lopez-Bautista, J.M.; Delwiche, C.F. \& Verbruggen, H. 2014. New phylogenetic hypotheses for the core Chlorophyta based on chloroplast sequence data. Frontiers in Ecology and Evolution 2:63. DOI: 10.3389/fevo.2014.00063

Fuhrmann, A.; Metzeltin, D. \& Tremarin, P.I. 2013. A triangular Eunotia (Bacillariophyceae) in southeastern Brazil: Eunotia trigona sp. nov. Acta Botanica Brasilica 27: 694-697.

Gama Jr, W.A.; Azevedo, M.T.P.; Komarková, J. \& Sant'anna, C.L. 2012. A new species of Lemmermanniella (Cyanobacteria) from the Atlantic Rainforest, Brazil. Brazilian Journal of Botany 35: 319-324.

Gama, Jr., W.A.; Laughinghouse, H.D. \& Sant'Anna, C.L. 2014. How diverse are coccoid cyanobacteria? A case study of terrestrial habitats from the Atlantic Rainforest (São Paulo, Brazil). Phytotaxa 178: 61-97.

Gómez, F. 2013. Reinstatement of the dinoflagellate genus Tripos to replace Neoceratium, marine species of Ceratium (Dinophyceae, Alveolata). CICIMAR Océanides 8: 1-22.

Grieneisen, M.L.; Zhan, Y.; Potter, D. \& Zhang, M. 2015. Biodiversity, taxonomic infrastructure, international collaboration, and new species discovery. BioScience 64: 322-332.

Guimarães, S.M.P.B. 2006. A revised checklist of benthic marine Rhodophyta from the State of Espírito Santo, Brazil. Boletim do Instituto de Botanica 17: 143-194.

Guiry, M.D. 2012. How many species of algae are there? Journal of Phycology 48: 1057-1063.

Guiry, M.D. \& Guiry, G.M. 2015. AlgaeBase. Worldwide electronic publication, National University of Ireland, Galway. Available at <http://www. algaebase.org $>$. Access on 15 May 2015.

Henriques, M.C.; Riosmena-Rodríguez, R.; Coutinho, L.M. \& Figueiredo, M.A.O. 2014. Lithophylloideae and Mastophoroideae (Corallinales, Rhodophyta) from the Brazilian continental shelf. Phytotaxa 190: 112-129.

Hentschke, G.S. \& Komárek, J. 2014. Scytonema santannae, a new morphospecies of Cyanobacteria 
from the Atlantic rainforest, southeastern Brazil. Brazilian Journal of Botany 37: 293-298.

Hero, J.M. \& Ridgway, T. 2006. Declínio global de espécies. In: Rocha, C.F D.; Bergallo, H. G.; Sluys, M. \& Alves, M.A.S. (org.). Biologia da conservação: essências. Rima, São Carlos. Pp. 53-90.

Jesus, P.B.; Guimarães, S.M.P.B. \& Nunes, J.M.C. 2013. Hypnea platyclada, a new species of red alga (Rhodophyta, Cystocloniaceae) from Brazil. Phytotaxa 85: 26-34.

Jesus, P.B.; Silva, M.S.; Lyra, G.M.; Nunes, J.M.C. \& Schnadelbach, A.S. 2015. Extension of the distribution range of Hypnea stellulifera (Cystocloniaceae, Rhodophyta) to the South Atlantic: Morphological and molecular evidence. Aquatic Botany 123: 26-36.

Joppa, L.N.; Roberts, D.L. \& Pimm, S.L. 2011. The population ecology and social behaviour of taxonomists. Trends in Ecology and Evolution 26: 551-553.

Jorge, R.R.; Harari, J. \& Fujii, M.T. 2012.Macroalgal composition and its association with local hydrodynamics in the Laje de Santos Marine State Park, southwestern Atlantic, São Paulo, Brazil. Brazilian Journal of Oceanography 60: 405-419.

Krienitz, L. \& Bock, C. 2012. Present state of the systematics of planktonic coccoid green algae of inland waters. Hydrobiologia 698: 295-326.

Leliaert, F.; Smith, D.R.; Moreau, H.; Herron, M.D.; Verbruggen, H.; Delwiche, C.F. \& DeClerck, O. 2012. Phylogeny and Molecular Evolution of the Green Algae. Critical Reviews in Plant Sciences 31:1-46.

Lyra, G.M.; Costa, E.S.; Jesus, P.B.; Matos, J.C.G.; Caires, T.A.; Oliveira, M.C.; Oliveira, E.C.; Xi, Z.; Nunes, J.M.C. \& Davis, C.C. 2015. Phylogeny of Gracilariaceae (Rhodophyta): evidence from plastid and mitochondrial nucleotide sequences. Journal of Phycology 51: 356-366.

Malone, C.F.S., Alvarenga, D.O.; Fiore, M.F. \& Leite Sant'Anna, C. 2014. Towards a phylogenetic position for the morphologically-defined genus Pannus (Cyanobacteria). Nova Hedwigia 99: 511-524.

Marin, B. \& Melkonian, M. 2010. Molecular phylogeny and classification of the Mamiellophyceae class. nov. (Chlorophyta) based on sequence comparisons of the nuclear- and plastid-encoded rRNA operons. Protist 161: 304-336

Menezes, M. \& Bicudo, C.E.M. 2009. Algas - Diagnóstico preliminar da biodiversidade no Brasil. In: Simpósio metas da convenção da biodiversidade para 2010: construindo a Lista de Espécies do Brasil. In: $60^{\circ}$ Congresso Nacional de Botânica. Universidade Estadual de Feira de Santana. Sociedade Botânica do Brasil, Feira de Santana. Pp. 59-64.

Menezes, M. \& Dias, I.C.A. (orgs.). 2001. Biodiversidade de algas de águas continentais do Estado do Rio de Janeiro. Museu Nacional, Rio de Janeiro: Série Livros 9: 1-256.
Metzeltin, D. \& Tremarin, P.I. 2011. Uma nova espécie de Eunotia para o sudeste do Brasil: Eunotia fuhrmannii. Iheringia, Série Botânica 66: 201-208.

Moreira-Filho, H.; Valente-Moreira, I.M. \& Mosimann, R.M.S. 1985. Catálogo de diatomáceas (ChrysophytaBacillariophyceae) Marinhas e estuarinas do Estado de Santa Catarina, Brasil. Ínsula 15: 33-88.

Moura, C.W.N.; Almeida, W.R.; Santos, A.A.; Andrade Junior, J.C.; Alves, A.M. \& Moniz-Brito, K.L. 2014. Polyphysaceae (Dasycladales, Chlorophyta) in Todos os Santos Bay, Bahia, Brazil. Acta Botanica Brasílica 28: 147-164.

Nauer, F.; Cassano, V. \& Oliveira, M.C. 2014a. Description of Hypnea pseudomusciformis sp. nov., a new species based on molecular and morphological analyses, in the context of the H. musciformis complex (Gigartinales, Rhodophyta). Journal of Applied Phycology 26:1-13.

Nauer, F.; Guimarães, N.R.; Cassano, V.; Yokoya, N.S. \& Oliveira, M.C. 2014b. Hypnea species (Gigartinales, Rhodophyta) from the southeastern coast of Brazil based on molecular studies complemented with morphological analyses, including descriptions of Hypnea edeniana sp. nov. and H. flava sp. nov. European Journal of Phycology 49: 550-575

Nunes, J.M.C.; Jesus, P.B.; Guimarães, S.M.P.B. \& Caires, T.A. 2014. Occurrence of the genus Tolypiocladia F. Schmitz (Rhodomelaceae, Rhodophyta) in the Atlantic Ocean. Botanica Marina 57: 147-151.

Oliveira Filho, E.C.; Horta, P.A.; Amancio, C.E. \& Sant'Anna, C.L. 2002. Algas e angiospermas marinhas bênticas do litoral brasileiro: diversidade, explotação e conservação. In: Workshop sobre avaliação e ações prioritárias para a conservação da biodiversidade da zona costeira e marinha. Relatório Técnico. MMA/FNMA/GEF, Brasília. Available at $<$ http://www.brasilrounds.gov.br/round7/arquivos r7/PERFURACAO_R7/refere/plantas_marinhas. pdf $>$. Access on 15 May 2015.

Pellizzari, F.; Oliveira, M.C.; Da Silva Medeiros, A.; Yokoya, N.S. \& Oliveira, E.C. 2013. Morphology, ontogeny, and phylogenetic position of Gayralia brasiliensis sp. nov. (Ulotrichales, Chlorophyta) from the southern coast of Brazil. Botanica Marina 56: 1-9.

Pellizzari, F.; Bernardi, J.; Silva, E.M.; Silva. M.C. \& Yokoya, N.S. 2014. Benthic marine algae from the insular areas of Paraná, Brazil: new database to the conservation of marine ecosystems. Biota Neotropica 14: 1-12.

Pereira, S.M.B.; Torres, J. \& Gestinari, L.M.S. 2014. Composition and distribution of deep water macroalgae species from the continental shelf of Sergipe state, Brazil. Phytotaxa 190: 250-267

Pimm, S.L.; Jenkins, C.N.; Joppa, L.N.; Roberts, D.L. \& Russell, G.J. 2010. How many endangered species remain to be discovered in Brazil? Natureza \& Conservação 8: 71-77. 
Procopiak, L.K.; Fernandes, L.F. \& Moreira Filho, H. 2006. Marine and estuarine diatoms (Bacillariophyta) from Parana, southern Brazil: check-list with emphasis on harmful species. Biota Neotropica 6: 1-28.

Ramos, G.P.R.; Bicudo, C.E.M. \& Moura, C.W.N. 2015. Oocystis apicurvata sp. nov. (Oocystaceae, Trebouxiophyceae), a new species of green algae from Chapada Diamantina, northeast Brazil. Brazilian Journal of Botany 38: 171-173.

Rocha, O. 2003. Águas Doces. In: Avaliação do estado do conhecimento da diversidade biológica do Brasil. Projeto Estratégia Nacional de Diversidade Biológica (Bra 97 G 31). Ministério do Meio Ambiente, Brasília. 70p.

Rocha-Jorge, R.; Cassano, V.; Barros-Barreto, M.B.; Diaz-Larrea, J.; Senties, A.; Gil-Rodriguez, M.C. \& Fujii, M.T. 2013. Osmundea sanctarum sp. nov. (Ceramiales, Rhodophyta) from the southwestern Atlantic Ocean. Phytotaxa 100: 41-56.

Sangster, G. \& Luksenburg, J.A. 2015. Declining rates of species described per taxonomist: slowdown of progress or a side-effect of improved quality in taxonomy? Systematic biology 64: 144-151.

Sant'Anna, C.L.; Azevedo, M.T.P.; Fiore, M.F.; Lorenzi, A.S.; Kaštovský, J. \& Komárek, J. 2011. Subgeneric diversity of Brasilonema (Cyanobacteria, Scytonemataceae). Brazilian Journal of Botany 34: 51-62.

Santos, K.R.S.; Malone, C.F.S.; Sant $>$ anna, C.L. \& Bicudo, C.E.M. 2013. Staurastrum pantanale sp. nov. (Zygnemaphyceae, Desmidiaceae), a new desmid species from the Brazilian Pantanal. Phytotaxa 90: 54-60.

Senna, P.A.C.; Souza, M.G.M. \& Compère, P. 1998. A check-list of the algae of the Federal District (Brazil). Ministry for SMEs and Agriculture, Directorate of Research and Development, National Botanic Garden of Belgium (Scripta Botanica Belgica Vol.16). National Botanic Garden of Belgium, Meise. 88p.

Sutherland, J.E.; Lindstrom, S.C.; Nelson, W.A.; Brodie, J.; Lynch, M.D.; Hwang, M.S.; Choi, H.-G.; Miyata, M.; Kikuchi, N.; Oliveira, M.C.; Farr, T.; Neefus, C.; Mols-Mortensen, A.; Milstein, D. \& Müller, K.M. 2011. A new look at an ancient order: generic revision of the Bangiales (Rhodophyta). Journal of Phycology 47: 1131-1151.

Tancoigne, E. \& Dubois, A. 2013. Taxonomy: no decline, but inertia. Cladistics 29: 567-570.

Tancoigne, E.; Bole, C.; Sigogneau, A. \& Dubois, A. 2011. Insights from Zootaxa on potential trends in zoological taxonomic activity. Frontiers in Zoology 8: 5. Available at $<\mathrm{http}$ ://www.frontiersinzoology.com/ content/8/1/5>. Access on 15 May 2015.
Torgan, L.C.; Becker,V. \& Prates, H.M. 1999. Checklist das diatomáceas (Bacillariophyceae) de ambientes de águas continentais e costeiras do estado do Rio Grande do Sul, Brasil. Iheringia, Série Botânica 52: 89-144.

Torgan, L.C.; Barreda, K. de A. \& Santos, C.B. 2001. Catálogo das algas Chlorophyta,de águas continentais e marinhas do estado do Rio Grande do Sul, Brasil. Iheringia, Série Botânica 56: 147-183.

Torgan, L.C.; Barreda, K. de A. \& Santos, C.B. 2003. Catálogo das algas Cryptophyta, Heterokontophyta, Dinophyta, Haptophyta e Rhodophyta de águas continentais e costeiras do Rio Grande do Sul, Brasil. Iheringia, Série Botânica 58: 227-250.

Torrano-Silva, B.N. \& Oliveira, E.C. 2014 a. Macrophytobenthic flora of the Abrolhos Archipelago and the Sebastião Gomes Reef, Brazil. Continental Shelf Research 70: 150-158.

Torrano-Silva, B.N.; Riosmena-Rodriguez, R. \& Oliveira, M.C. 2014b. Systematic position of Paulsilvella in the Lithophylloideae (Corallinaceae, Rhodophyta) confirmed by molecular data. Phytotaxa 190: 94-111.

Tremarin P.I.; Freire, E.G.; Bertolli, L.M. \& Ludwig, T.A.V. 2009. Catálogo das diatomáceas (OchrophytaDiatomeae) continentais do estado do Paraná. Iheringia, Série Botânica 64: 79-107.

Tremarin, P.I.; Ludwig, T.A.V. \& Torgan, L.C. 2012. Ultrastructure of Aulacoseira brasiliensis sp. nov. (Coscinodiscophyceae) and comparison with related species. Fottea 12: 171-188

Tremarin, P.I.; Freire, E.G. \& Ludwig, T.A. 2013a. Ultrastructure and distribution of Urosolenia obesa sp. nov. (Rhizosoleniaceae, Diatomeae) in reservoirs from southern Brazil. Phytotaxa 125: 1-9.

Tremarin, P.I.; Paiva, R.S.; Ludwig, T.V., \& Torgan, L.C. 2013b. Aulacoseira calypsi sp. nov. (Coscinodiscophyceae) from an Amazonian lake, northern Brazil. Phycological Research 61: 292-298.

Tremarin, P.I.; Ludwig, T.A.V. \& Torgan, L.C. 2014. Aulacoseira veraluciae sp. nov. (Coscinodiscophyceae, Aulacoseiraceae): a common freshwater diatom from Brazil. Phytotaxa 184: 208-222.

Wetzel, C.E.; Lange-Bertalot, H.; Morales, E.A.; Bicudo, D.C.; Hoffmann, L. \& Ector, L. 2012a. Bicudoa amazonica gen. nov. et sp. nov. (Bacillariophyta) - a new freshwater diatom from the Amazon basin with a complete raphe loss in the Eunotioid lineage. Phytotaxa 75: 1-18.

Wetzel, C.E.; Van de Vijver, B.; Cox, E.J.; Bicudo, D.D.C. \& Ector, L. 2012b. Tursiocola podocnemicola sp. nov., a new epizoic freshwater diatom species from the Rio Negro in the Brazilian Amazon Basin. Diatom Research 27: 1-8. 